\title{
EFFECT OF SELF EFFICACY AND ORGANIZATIONAL CITIZENSHIP BEHAVIORS ON EMPLOYEE SATISFACTION
}

\author{
${ }^{1}$ Siti Samsiyah, ${ }^{2}$ Roza Monica Sintia Dewi \\ ${ }^{1 \& 2}$ Faculty of Economics and Business, Universitas PGRI Adi Buana Surabaya, Indonesia \\ Email : sitisamsiyah@unipasby.ac.id
}

\begin{abstract}
:
Human resources become a major problem in various activities with ina Company, especially in the field of organizational. This research aimstotest And analyze the employee satisfaction of PT. Sinar Karya Abadi's work Which is influenced by the variable of self-efficacy and behaviour of the Citizenship organization. The population amounted to500 employees and obtained samples amounting to 85 respondents consisting of employees of PT. Sinar Karya Duta Abadi. Simple random sampling is a sampling technique that uses the utility. Obtained data from the propagate then recollected the questionnaire and used techniques analyzed multiple linear regression and hypotheses tests. Available work satisfaction results gain Influence from free variables. That result illustrates the free variables having an influence on the dependent variables. It is hoped that this research can be Used as a reference where PT. Sinar Karya Duta Abadi can improve employee satisfaction through self-efficacy and behaviour of the nationality organization, if the two traits are owned by each individual, then the organizational productivity increases.
\end{abstract}

Keywords : $\quad$ Self-Efficacy, Organizational Citizenship, Behavior, Job Satisfaction

\section{Introduction}

In today's era, companies need to continue to develop creative, innovative products and services so that they are able to adapt to competitors. Because of that, human resources play an important role. The company should prepare employees who are of suitable quality in the future and are able to carry out their duties. To achieve a goal, employees basically must have Self Efficacy (self-efficacy). When the world of work is very complex, the employees that the company needs are not only able to do their own part of the job, but are also willing to do extra tasks and strive to advance the company. This behavior is known as the Organizational Citizenship Behavior. The Citizenship Organizational Behavior will be realized if it fulfills the job satisfaction of its employees. From the research that has been done, this company started its journey on February 22, 1993 and then started operating on June 22, 1995. This company is engaged in the ceramic industry where the products produced are SNI certified and the operational aspects also meet ISO standards. From its inception until now this company has been able to survive with a good reputation in the ceramic industry and remains a quality product manufacturer that is always competent to continue to innovate to produce quality products with creative designs. Self Efficacy (self-efficacy) is a person's belief in his or her abilities regarding the chances of success in completing work tasks and achieving certain results, Kreitner\& Kinicki (2014: 125).

All company achievements are inseparable from the role of its employees who do their job well and on time and have high OCB. The company has skilled employees who can create a company that continues to grow rapidly and get many achievements. From the exchange of information with HRD, it was found that the company always had a way to convince its employees of the ability to make an action. One way for the company is to provide direction to 
employees if they encounter a problem, it is intended to train self-confidence in overcoming the problems they encounter. Because when employees already have self-confidence they will be able to manage their time well and be able to control their abilities very well. This will create a confident attitude of employees to always produce the best and achieve goals. Explaining that self-confidence is related to a person's belief related to his competence and ability to get maximum results, Burso (2018).

Through researchers during studies and light interviews with one or two employees, taking the initiative to help solve other employees' problems. Meanwhile, job satisfaction that is felt by all employees is not the same, because every employee has a different point of view about everything depending on how employees react to their work. The increase in the work productivity of employees and the creation of a more motivated self to be more developed and more advanced in their work organization, will all be created when employees are satisfied with what they are doing. Conversely, when the employee feels dissatisfied, it can be observed how his attitude is in his workplace. When there is absenteeism, a decrease in productivity and even more so when a strike occurs, it will all occur when employees are truly dissatisfied with what the company provides. Therefore, it is important for companies to continue to monitor the desires of their employees so that the company can still achieve goals and develop the company organization. Therefore, it is important the meaning of job satisfaction for employees and company organizations when complementing each other's organization in order to keep developing and healthy.

\section{Literature Review}

\section{Definition of Self Efficacy}

According to Bandura (1997) in Ghufron and Risnawati (2017: 75), that a person's self-stability towards his skills to achieve the desired goals. There are 3 indicators of self-efficacy, namely, 1) the level (level) which is meant by the selection of behavior that will be tried or avoided by an individual.The level of self-efficacy in each individual is different from one another, the level of difficulty of the task will determine a person's Self-efficacy. (2) Strength, which places more emphasis on the level of strength or the individual's stability towards their beliefs. and generalization (Generality) Individuals with high self-efficacy will be able to master several fields at once to complete a task. Bandura (1997) in Ghufron and Risnawati (2017: 80-81).

\section{Definition of Citizenship Organizational Behavior}

In Organs, et al. (2006) in Titisari (2014), explained individual initiatives that are not related to the reward system that applies to the organization. The Citizenship Organizational behavior will provide benefits for the company because with it employees have indirectly contributed outside of their individual duties. There are five dimensions of Citizenship Organizational Behavior, namely: Selflessness, caution, sportsmanship, politeness and civic virtue.

\section{Definition of Job Satisfaction}

Gibson in Sudaryo et al (2018: 76), explains the responses that workers have to the work they do. In Sudaryo et al (2018: 90), there are 6 indicators, namely: a) Wages or salaries received, according to a level that is considered equivalent in return for services provided to the company, b) Tasks, namely the content of work performed by someone, c) co-workers who provide support, advice or advice to other colleagues can increase job satisfaction, d) a leader who 
International Journal of Economics, Business, and Accounting Research (IJEBAR)

Peer Reviewed - International Journal

Vol-5, Issue-1, 2021 (IJEBAR)

E-ISSN: 2614-1280 P-ISSN 2622-4771

https://jurnal.stie-aas.ac.id/index.php/IJEBAR

always gives orders or instructions in carrying out work, e) promotions or opportunities to improve careers also have an impact on employee job satisfaction, f) work situation, namely a comfortable and conducive atmosphere and work environment. Kinicki and Fugate (2012) in Kaswan (2015) state that job satisfaction is an affective or emotional reaction to various aspects of a job.

\section{Hypothesis}

It is in relation to this study that the hypothesis is:

H1: Self efficacy affects the job satisfaction of employees of PT. SinarKarya Duta Abadi.

H2: OCB affects the job satisfaction of employees of PT. SinarKarya Duta Abadi

H3: Self efficacy and OCB affect job satisfaction of employees of PT. SinarKarya Duta Abadi

\section{Research Results}

The sample is a part or representative of the population under study. It is called sample research if we intend to generalize the results of sample research, Arikunto (2013: 173). The research location was carried out at PT. SinarKarya Duta Abadi. The sampling method uses Simple Random Sampling. The population is 500 employees with a sample of 85 respondents.

\section{Data Analysis \\ Validity Test}

\section{Table.1}

\begin{tabular}{lcccc}
\hline & $\begin{array}{c}\text { Correction, item- } \\
\text { total repaired the } \\
\text { highest }\end{array}$ & $\begin{array}{c}\text { Correction, item- } \\
\text { total repaired } \\
\text { lowest }\end{array}$ & $\begin{array}{c}\mathrm{R} \\
\text { Table }\end{array}$ & Information \\
\hline $\mathrm{X} 1$ & 0,832 & 0,687 & 0,2133 & Valid \\
$\mathrm{X} 2$ & 0,810 & 0,472 & 0,2133 & Valid \\
$\mathrm{Y}$ & 0,777 & 0,382 & 0,2133 & Valid \\
\hline
\end{tabular}

$\mathrm{R}$ table has a value of 0.2133 where the results indicate valid data.

According to Ghozali (2013: 48) the reliability test is a tool to measure a questionnaire which is an indicator of a variable or construct. A questionnaire is said to be reliable or reliable if a person's answer to a statement is consistent or stable over time.

\section{Reliability Test}

Table.2

\begin{tabular}{clc}
\hline & CA Value & Information \\
\hline$(\mathrm{X} 1)$ &, 874 & \\
$(\mathrm{X} 2)$ &, 865 & Reliable \\
$(\mathrm{Y})$ &, 778 & \\
\hline
\end{tabular}


International Journal of Economics, Business, and Accounting Research (IJEBAR)

Peer Reviewed - International Journal

Vol-5, Issue-1, 2021 (IJEBAR)

E-ISSN: 2614-1280 P-ISSN 2622-4771

https://jurnal.stie-aas.ac.id/index.php/IJEBAR reliable.

In the table above the value obtained (>0.70), it is concluded that all variables are declared

Normality Test

Table. 3

1-Sample-K-S

Residuals are not standardized

Asy Sig.(2-tailed) 200

From the table above the asymp.sig value (0.200> significant level), which states that the data has a normal distribution.

\section{Multicolonierity Test}

Table.4

\begin{tabular}{lll}
\hline & Tolerance & VIF \\
\hline $\mathrm{X}^{1}$ & .900 & 1,112 \\
$\mathrm{X}^{2}$ & .900 & 1,112 \\
\hline
\end{tabular}

The tolerance value of the two independent variables is $0.900>0.10$. While the VIF value of the two independent variables is $1.112<10$. It can be said that there is no correlation in the independent variable.

\section{Heteroskedastistics Test}

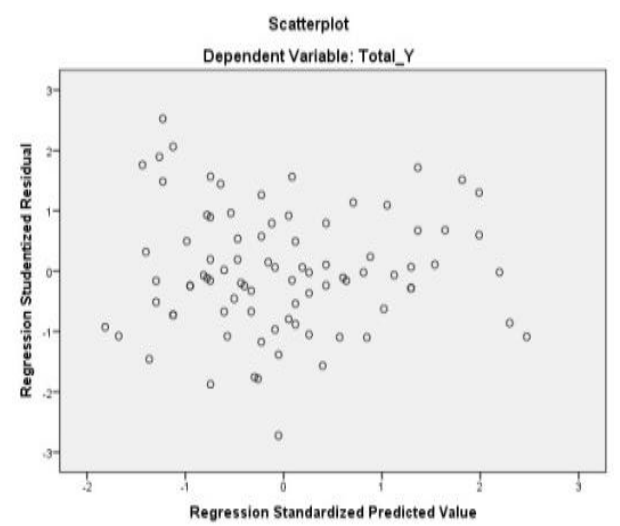

Image.1

As the above picture exposure, the data spreads irregularly without making a certain pattern, it means that there is no heteroscedasticity.

Autocorrelation Test

Table.5

Durbin-Watson 
International Journal of Economics, Business, and Accounting Research (IJEBAR)

Peer Reviewed - International Journal

Vol-5, Issue-1, 2021 (IJEBAR)

E-ISSN: 2614-1280 P-ISSN 2622-4771

https://jurnal.stie-aas.ac.id/index.php/IJEBAR

\section{1,675}

Obtained DW value is $1.675, \alpha=5 \%, \mathrm{n}=85, \mathrm{k}=2, \mathrm{dL}=1.599, \mathrm{du}=1.696$. Because the DW value of 1.675 is between $\mathrm{dl}$ and 4 -du, which is equal to $1.5995<1.675<2.3043$, which means there is no autocorrelation.

Multiple Linear Regression Analysis

Table.6

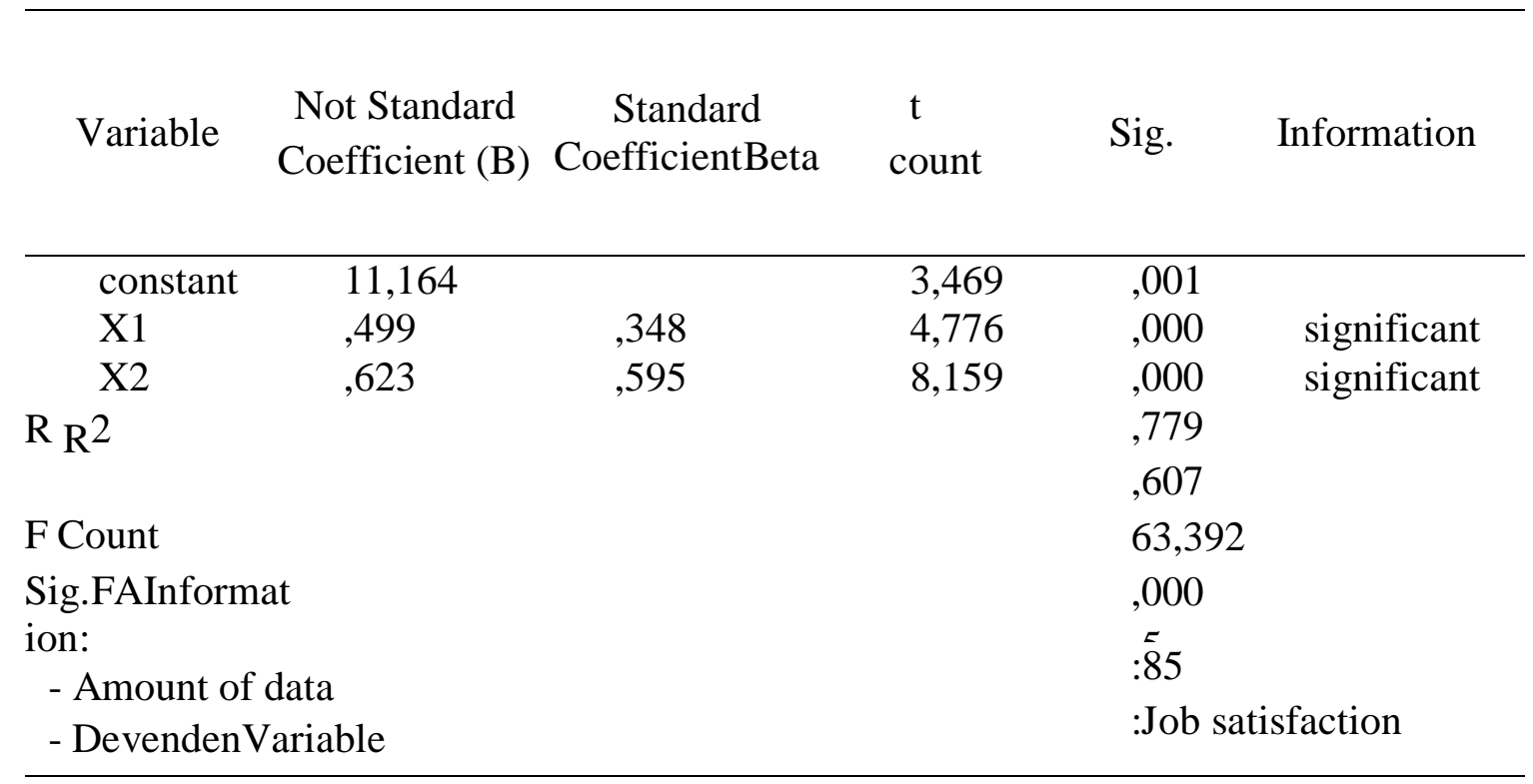

From the test results obtained:

a) Correlation Coefficient

$\mathrm{R}=0.779$ means that the correlation between the independent variable and the dependent variable is $77.9 \%$.

b) Coefficient of Determination

$\mathrm{R}$-Square $=0.607$ means that the independent variable can affect the dependent variable by $60.7 \%$, meanwhile

$39.3 \%$ is influenced by other variables.

c) Equations of Regression Lines

Obtained discussion:

1) The constant value in table 5 is 11,164 . Then it can be explained the value (X1 and $\mathrm{X} 2=0$ ), then the $\mathrm{Y}$ value is 11.164 .

2) The regression coefficient $X 1$ is 0.499 and $X 2$ is 0.623 . The positive sign of the regression coefficient shows that $\mathrm{X} 1$ and Serta $\mathrm{X} 2$ and $\mathrm{Y}$ are equal to have a unidirectional relationship. 


\section{Hypothesis Testing \\ Partial hypothesis testing (t-test)}

Table.7

\begin{tabular}{|l|l|l|}
\hline & \multicolumn{1}{|c|}{$\mathrm{t}$} & \multicolumn{1}{c|}{ Sig } \\
\hline Total X1 & 4,776 &, 000 \\
Total X2 & 8,159 &, 000 \\
\hline
\end{tabular}

\section{Simultaneous hypothesis Testing (F test)}

Table.8

\begin{tabular}{|c|c|}
\hline $\mathrm{F}$ & Sig \\
\hline 63,392 &, $000^{b}$ \\
\hline
\end{tabular}

\section{Proof of Hypotheses and Discussion}

The results of this study indicate that $\mathrm{H} 0$ is rejected and $\mathrm{H} 1$ is accepted because the t-value of X1 is 4.776 along with a significance value of 0.00 , which is lower than 0.05 . Which means that Self-efficacy has a significant effect on Employee Job Satisfaction.

This research is a civilization from research of Salangka and Dotulong (2015) [9] as well as research by Putri and Wibawa (2016) [10] which states that there is a positive and significant influence of the Self Efficacy variable on Job Satisfaction.

Hypothesis 2 test results state that $\mathrm{H} 0$ is rejected and $\mathrm{H} 2$ is accepted because the t-value of $\mathrm{X} 2$ is 8.159 along with a significance value of 0.00 which is lower than 0.05 . Which means that Organizational Citizenship Behavior has a significant effect on job satisfaction.

The results of a study from Chaerani and Nimran (2018) [11] where the results of the study explain that Organizational Citizenship Behavior has a significant effect on one-way Job Satisfaction with the results of this study.

For the simultaneous hypothesis, results are obtained where the f-count is 63.392 along with a significance value of 0.00 which is lower than 0.05 . So that it can be stated that the F-test results show that all variables simultaneously have a positive and significant effect on the dependent variable, namely Job Satisfaction.

\section{Conclusion}

Self Efficacy OCB both independently have a positive and significant effect on employee job satisfaction. The results were obtained based on the existing tests in the t-test and f-test, there were results that stated that the hypothesis was accepted and its validity was proven. Thus, the high self-efficacy of OCB employees will increase job satisfaction, so organizational productivity can achieve a goal well. 


\section{Reference}

Arikunto, Suharsimi. 2013. Research Procedure: A Practical Approach. Jakarta: Rineka Cipta. Busro, Muhammad. (2018). Human Resource Management Theories, Prenada Media.

Chaerani and Nimran, 2018, The Influence of Organizational Citizenship Behavior (Ocb) on Job Satisfaction (Studies on Employees of the Human Capital Division of Pt. Bank Negara Indonesia (Persero), Tbk.) ". Brawijaya University Malang. Journal of Business Administration (Jab). Vol. 60 No. 2.

Ghazali, Imam. 2013. Application of Multivariate Analysis with the IBM SPSS 21 Update PLS Regression Program. Semarang: Diponegoro University Publishing Agency.

Ghufron, M. and Risnawati, N.R., 2017, Psychological Theories, Yogyakarta: Ar-Ruzz Media.

Kaswan. (2015). Work Attitudes: From Theory and Implementation to Evidence. Bandung: Alfabeta.

Kreitner, R., Kinicki, A., 2014. Organizational Behavior, 9th Edition, Book 1, Jakarta: SalembaEmpat.

Putri and Wibawa, 2016, The Influence of Self Efficacy and Work Motivation on Job Satisfaction of Employees at the Equipment Section of the Klungkung Regency Secretariat, Management E-journal of Udayana University, Vol. 5, No, 11, 2016: 73397365.

Salangka, L. and Dotulong, L., 2015, The Influence of Self Efficacy, Self Esteem and Work Environment on Employee Job Satisfaction at PT. PLN (PERSERO) Wilayah Suluttenggo, Journal of EMBA, Vol. 3 (3) 562-572.

Sudaryo, Yoyo, et al, 2018, Human Resource Management, Indirect Compensation and Physical Work Environment, Yogyakarta: CV Andi Offset.

Titisari, Purnamie, 2014, The Role of Organizational Citizenship Behavior (OCB) in Improving Employee Performance, Jakarta: Mitra Wacana Media. 